\title{
STABILITY OF LEADERSHIP AS A DETERMINANT IN THE DEVELOPMENT OF BUDGETARY UNITS IN POLAND
}

\author{
Kinga Gruziel ${ }^{凶}$ \\ Warsaw University of Life Sciences - SGGW, Poland
}

\begin{abstract}
This study investigates the concept of the stability of the state and the public finance sector (PFS) based on a review of current literature in the field. An attempt has been made to define the principles of public management and present the structures of public finance sector units (PFSU) in Poland. The study focuses on the public finance sector, units included in this sector, mechanisms influencing the functioning of public service organisations and their management. Part of the research is a case study analysis of a sample PFSU, which is a central administration body. The purpose of the study was to identify the measures used to assess the stability of a public finance sector unit and to interpret those measures in relation to the studied areas of the PFS in Poland. The paper explores the principles of managing the organisation of the public finance sector, the notion of public management and its genesis. The selected PFSU case was used to indicate the relationship between the functioning of a public finance sector unit and the stability of leadership in that unit. The study is descriptive and uses inference methods. The research material included the literature on public finance and management as well as internal materials of the studied public finance sector unit. The main objective of the study was to show how the destabilisation of leadership can affect the functioning of the state office. As a result of the analysis, measures most accurately describing the phenomenon of leadership stability have been constructed. They include: measures based on quantitative assessment, measures based on institutional behaviour assessment and measures based on the subjective opinions, behaviours and expectations of employees, stakeholders and associates of the PFSU. The existence of a relationship between the stability of leadership and the functioning of a public finance sector unit was confirmed. Changes were recorded in the functioning of the office during frequent personnel changes in senior civil service positions.
\end{abstract}

Key words: public finance sector, stability, public management

JEL codes: H41, H72, H83, E6

\section{INTRODUCTION}

In the literature, the term "stability" is usually placed in the context of political stability of a state and is used by analysts and researchers to determine the condition of a given state or assess the effects of implemented policies. The review of the literature, conducted in order to explore the concept of stability itself, its essence, measures and effects, revealed a three-fold approach. The researchers focus on legal aspects and constitutional conditions of the stability of state organs, the stability of the state in the international dimension or identification of factors that may impact the effectiveness of management and functioning of individual organisations, e.g. local governments or budgetary units. 
The stability of the state in the constitutional dimension is indispensable for the existence of an organised political and social community, as well as the institutions representing authority whose role is to protect the functioning and existence of the community [Weber 1998, p. 56]. The lack of a stable government leads to both economic and social crises, which in turn contributes to changes at the highest levels of power. To avoid cycles of adverse phenomena, the recommended solution is to define the state authority in compliance with the constitutional principles and the stability and effectiveness of the executive power [Balicki 2018, p. 206]. Shepherd [2010, p. 8] suggests that political stability, unrelated to any type of political regime, should be a way of exercising power aimed at achieving positive effects. Shepherd equates political stability with the notion of good governance, i.e. good administration, understood as making and implementing decisions by public institutions at various levels of power and maintaining relationships with civil society organisations. Entities that directly experience the effects of decisions participate indirectly in taking those decisions. In the literature on the subject, stability is defined as the ability of the organizational units of these sectors to provide public services without negative consequences in the future [Bath 2001, pp. 7-8, Navarro-Galera et al. 2016, pp. 3961-3975].

Nowadays, the new public management concepts appear in the literature on public service organisation management, including innovative research and implementations aimed at adapting ideas, methods, techniques and institutional solutions utilized in the private sector to the public finance sector [Lubińska 2011, p. 52]. The need to have managerial skills while governing a budgetary unit is becoming a necessity, especially in the situation of limited financial resources for the implementation of basic local government tasks, the burdening of local governments with additional tasks and increased social pressure. Therefore, the stability of leadership and effectiveness of public sector entities depends on effective public management following a set of principles, which every good manager should respect. These include: caring for people, being culturally aware, defining clear goals, pursuing self-improvement, communicating effectively, setting efficient control system and defining the vision of success [Kuźmiński 2020, pp. 62-67].

\section{SUBJECT AND SCOPE OF THE STUDY}

This study involved an analysis aimed to determine the principles of functioning of the public finance sector unit - PFSU (jednostka sektora finansów publicznych) in terms of the implementation of its statutory tasks against a backdrop of frequent leadership changes at the top of the organisation. The investigation focused on the public finance sector in Poland, units included in this sector and mechanisms influencing their functioning and management. Part of the research is a case study analysis of an exemplary PFSU - the Central Office of Measures (Główny Urzad Miar), which is the central organ of Polish administration and is subject directly to the minister responsible for economy. The research covered the years 2011-2017, which made it possible to identify changes in the functional structure of the analysed public finance sector unit.

The main objective of this study was to identify measures utilised to assess the stability of a public finance sector unit and to interpret these measures in relation to the studied areas of public finance sector operations in Poland. The study explores the principles of managing the organisation of the public finance sector, the notion of public management and its origins. The case study of the public finance sector unit was an attempt to demonstrate the relationship between the functioning of a public finance sector organisation and the stability of leadership in that unit.

\section{PUBLIC MANAGEMENT}

The state economy consists of two sectors: private and public. The private sector is the result of free market operations, happenings and interdependencies while the public sector results from public and political decision-making processes. The public sector pursues a predefined mission, which is to provide goods and services to the citizens of a given country. The activities undertaken within the public sector ensure national security, social assistance and spatial planning. 
The public sector covers the functions of the state, expenses incurred for their implementation, ownership of state assets and funds and the way they are used [Zawicki 2011, p. 11]. The scope of state and public administration activities comprises tasks assigned only to the public sector. The main tasks include: defence and military tasks, defence policy, equipment and functioning of the army as well as ensuring legal and institutional order. The latter also includes tasks related to internal security and protection of property and freedom of individuals. The specificity of public organisations is contained in their mission, goals and values.

Strategic management in public administration is analysed as an instrument of exercising power through decision-making processes ensuring the rationalisation of conducted operations. The primary task is the choice of development directions for a given unit by including public managers in the process of planning and coordinating operations [Prowle 2000, pp. 22-24].

The implementation of strategic management in public administration is the result of the reorganisation of the public sector, its modernisation and rationalisation. The public finance sector exhibits certain specific characteristics that distinguish it from many other economic sectors [Navarro-Galera et al. 2016, pp. 3961-3975]. The conditions for efficient implementation of strategic management include: specifying the mission, organisational goals, rules and conditions for assessing the status of a given entity; measuring results; giving public managers a greater scope of responsibility; increasing their flexibility within the scope of unit structures and resource distribution; and implementing managerial methods and techniques. It follows from the above that strategic management is closely related to the managerial approach, which was created on the basis of so-called the new public management [Włóka and Jędrzejas 2014, pp. 88-100] and is currently being adopted in Polish public institutions.

\section{THE STRUCTURE AND FUNCTIONING OF PUBLIC FINANCE SECTOR UNITS IN POLAND}

Units of the public finance sector form a very complex structure in terms of their organisation and distribution of power. Government administration at the central level comprises the President of the Council of Ministers (Prime Minister), individual ministries, central offices and agencies. The organs directly accountable to the Council of Ministers include: central offices and organisational units of special administration; central organs and organisational units; the voivodes (governors of regions) together with the voivodship office and regional courts, which are directly controlled by the Council of Ministers. The territorial self-government units in Poland since 1 January 1999 are broken down by voivodship (województwo), county (powiat) and commune/municipality (gmina), established by the Act of 24 July 1998 on the introduction of a basic three-tier territorial division of the state.

One control instrument in the public finance sector is the internal audit, whose aim is to assess the correctness, efficiency and effectiveness of public finance sector units and the rationality of spending the funds at their disposal. The scope of control activities as part of an internal audit is based on verifying the assumptions and objectives of the PFSU, which include:

- clearly defined organisation goals,

- introduction of procedures for monitoring the achievement of objectives,

- timeliness and compliance with procedures,

- use of tools to measure the effectiveness and efficiency of achieving the objectives,

- identifying, assessing and managing risk related to achieving the adopted objectives.

Verification of the effect of monitoring activities includes: comparative analysis of the level of public expenditure in recent years; an assessment of adopted legal and organisational regulations in the field of public funds management in the organisation; and evaluation of the criteria for assessing the effectiveness and efficiency of planning and spending [Skoczylas-Tworek 2013, pp. 198-199].

External control is exercised by the principal state audit body, which in the public finance sector is the Supreme Audit Office (Najwyższa Izba Kontroli). Its audit procedure follows five main principles:

- The principle of a separate regulation of the audit proceedings conducted by the Supreme Audit Office. The audit proceedings should be conducted under the provisions of a separate law - the Supreme Audit Office Act. 
- The principle of planning and programming of audits (audits are conducted in accordance with an audit plan adopted by the College of the Supreme Audit Office).

- The principle of objective truth (audit findings reflect the actual state of operations of the audited entity and are thoroughly documented).

- The principle of contradictory procedure (the head of the audited entity has the right to use different appeal procedures).

- The principle of written form (all audit activities take a written form).

Stability is associated with predictability, reducing the risk of unexpected changes and thus control over the system or phenomenon to which the stability relates. Stability is therefore a positive phenomenon, generating the desired effect also from the point of view of public finances. Ensuring stability also implies responsibility for the proper performance of all tasks involving public funds.

\section{DESCRIPTION OF THE STUDIED PUBLIC FINANCE SECTOR UNIT}

The public finance sector unit selected for the case study is the central body of government administration, accountable to the minister appropriate for economy - the Minister of Entrepreneurship and Technology. Central government administration bodies to which the central office is subject exercise supervision over it. These bodies also have impact on the appointment of central office managers, on the structure of the office as well as on its operations. In the Acts, the central office appears as a one-man body - the President of the Central Office of Measures.

The nature of the analysed PFSU's operations illustrates the current system of governance as well as the organisational structure in the examined institution. However, over the years 2011-2017 a number of changes and modifications were introduced which significantly affected the functioning of the unit. According to the data published in the previous Bulletin of Public Information, in the past, the Directors General remained in the post for at least several years, which allowed them to get to know the specifics of the functioning of the Office, the nature of its activities, the expertise in the area of both the civil service and public finances as well as in the scientific field that the Office deals with on a daily basis. As demonstrated in the table, changes in the position of Director General of the Office became more frequent.

The significance and rank and function of the Director General position is confirmed by the scope of tasks assigned to the Director General and resulting from the Civil Service Act of 21 November 2008. Among the Director General's tasks, the Act lists obligations related to ensuring the continuity of the office's operation, obligations in the field of labour law towards persons employed in the office, and implementation of HR policy.

In 2010, the Central Office of Measures drew up a document specifying its strategic goals for period 2010-2015 [GUM 2010]. The strategy set four main directions for future development of the office. The conducted analysis of the operations of the Central Office of Measure in years 2011-2017 showed

Table. Time in post of Director General in the Central Office of Measures

\begin{tabular}{lc}
\hline Dates of holding the post of Director General & Time in post of Director General \\
\hline $26.11 .1997-31.05 .2011$ & 13 years 6 months \\
\hline $11.10 .2012-20.01 .2016$ & 4 years 3 months \\
\hline $17.02 .2016-18.05 .2016$ & 3 months \\
\hline $19.05 .2016-03.04 .2017$ & 10 months \\
\hline $06.04 .2017-$ Till now & more than a year
\end{tabular}

Source: Bulletin of Public Information of the Central Office of Measures. 
Gruziel, K. (2020). Stability of leadership as a determinant in the development of budgetary units in Poland. Acta Sci. Pol. Oeconomia 19 (4), 41-49, DOI: 10.22630/ASPE.2020.19.4.39

changes in its functioning in strategic areas as a result of leadership changes at the top of the organisation. This change in leadership is also reflected by dynamics in the volatility of revenue, expenditure, employment and average gross salary earned by the Office employees. Based on the annual audit reports of the Supreme Audit Office for 2011-2017, we selected facts and figures that clearly indicate imbalances and highlight changes in the field of revenue, expenditure, number of employees and average salary.

The figures for the PFSU revenue in 2011-2017 compiled in Figure 1 indicate that since 2015 there was a significant increase in the recorded revenue compared to the plans included in the Budget Act and also when compared to the entire period under examination. The highest level of recorded revenue was achieved in 2016, when it exceeded the revenue planned in the Budget Act by $19.4 \%$. In 2017, the sum of generated revenue showed a downward trend.

An analogous trend can be observed with regard to PFSU's spending in 2011-2017 presented in Figure 2. From 2015, expenditures showed an upward trend until reaching the highest level in 2017.

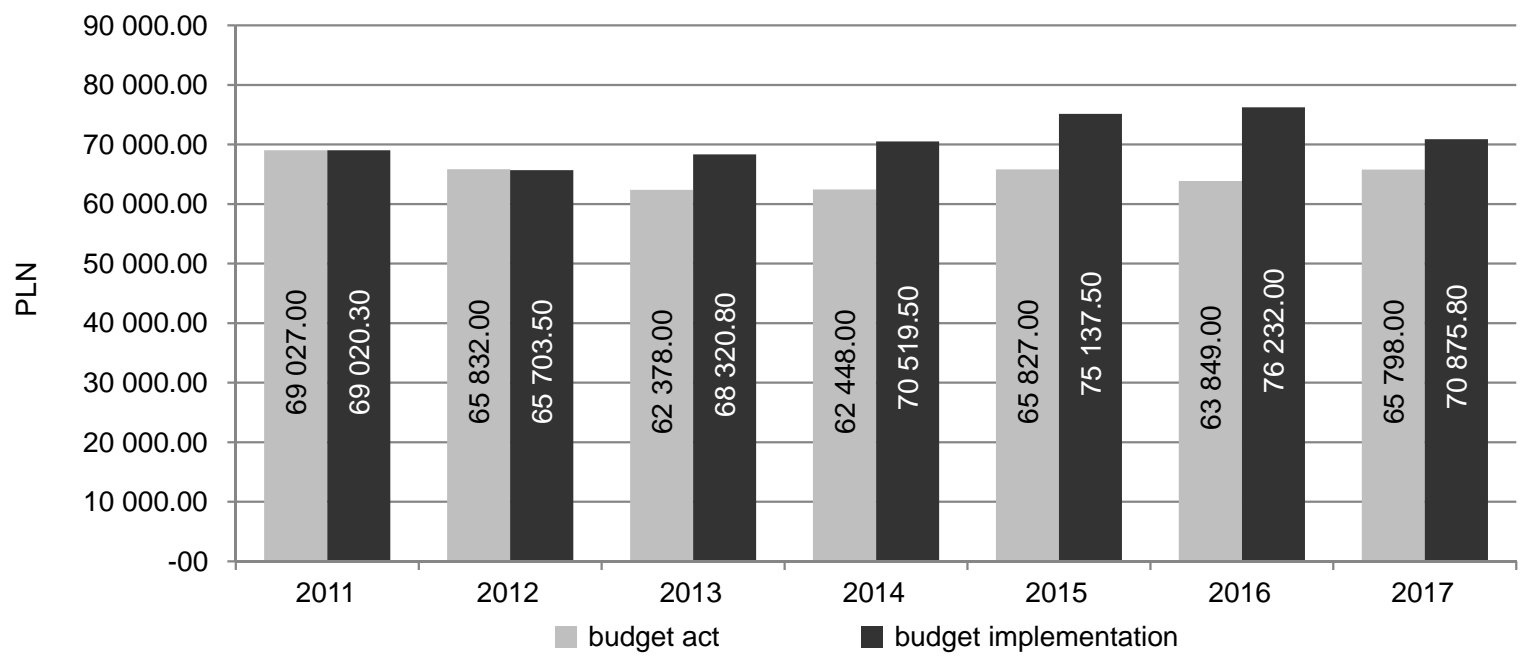

Fig. 1. Revenue of the Central Office of Measures in years 2011-2017

Source: Annual audit reports of the Supreme Audit Office [NIK 2011-2017].

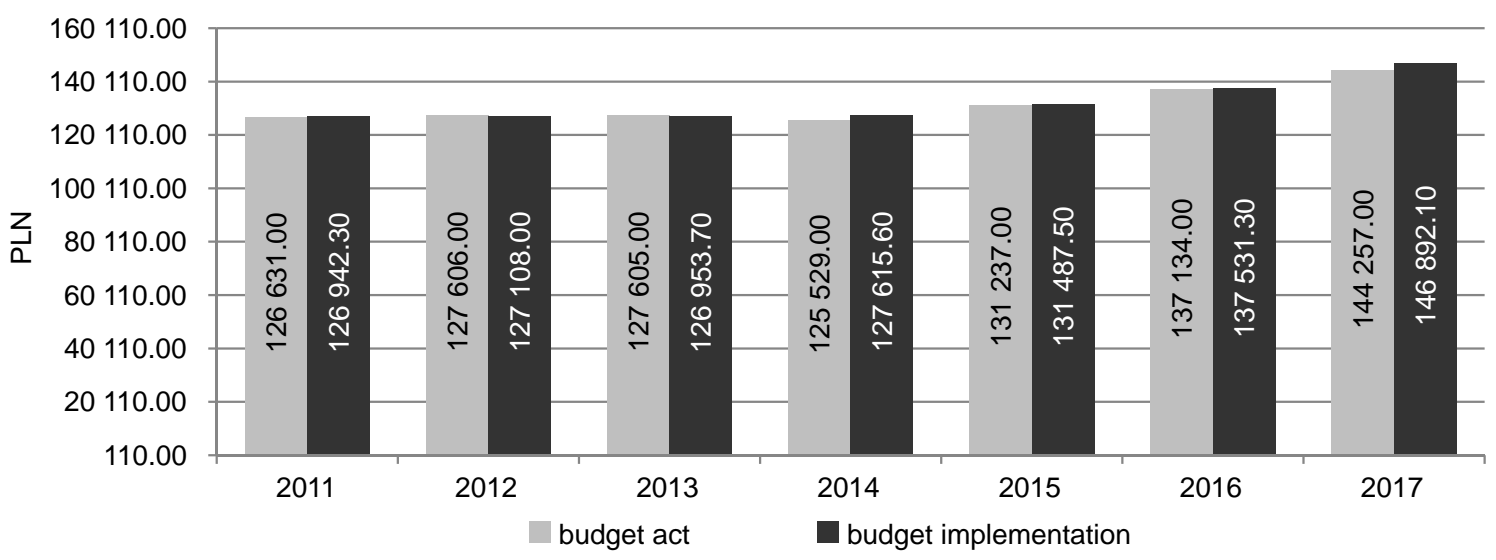

Fig. 2. Incurred expenditure of the Central Office of Measures in years 2011-2017

Source: Annual audit reports of the Supreme Audit Office [NIK 2011-2017]. 
In 2012 and 2013, the level of planned expenditure was not exceeded. Many investment purchases were made regarding the subject of metrology, but also purchases related to the brand image of PFSU, which so far had not been incurred to such an extent. In order to show the differences in the examined period of 2011-2017 , on the implementation of revenue and expenditure in a public finance sector unit.

The data from Figure 2 clearly demonstrate that since 2015 there has been a change in the levels of revenue and expenditure. The illustrated revenue values showed an upward trend in 2013-2016, followed by a downward trend in 2017 with expenditure values that showed an upward trend from 2016.

In addition the analysis of figures regarding employment and average gross salary of the PSFU's employees in 2011-2017 reveals significant changes. The data are presented in Figure 3.

The juxtaposition of figures representing the number of people employed in the analysed PFSU in the period 2011-2017 shows that despite an observed gradual decline in employment, in 2016 there was a slight increase in the number of employees, followed by a visible decrease in 2017 . The demonstrated level of average gross salary since 2016 shows a significant upward trend. In the years 2011-2017 employees' salaries showed a uniform upward trend, however, the increase in remuneration compared to the previous year varied. Salary increases ranged between 0.3 and $6.11 \%$, where the highest increase was recorded between 2015 and 2016 and the lowest between 2011 and 2012. The maximum average gross salary was recorded in 2017 and reached almost PLN 5,000. If we compare the average gross salaries of the PFSU's employees to the average gross salary in the national economy over the years 2011-2017, it is noticeable that the increase in the average national salary showed different growth amplitude and fluctuated between 2.84 (2012-2013) and 5.58\% (2016-2017).

\section{MEASURES OF LEADERSHIP STABILITY IN PUBLIC FINANCE SECTOR UNIT}

The literature discussing the determination of measures of stability proposes measures of financial stability. Some of the most appropriate measures of stability were selected and applied to the object of this study - a public finance sector unit - in order to ultimately develop, describe and evaluate the measures of leadership stability.

- Measures based on quantitative assessment: value of received revenue, average monthly gross salary of full-time employees, lack of rapid changes in the value of expenditure, lack of sudden changes in the number of employees,

- Measures based on subjective opinions, behaviours and expectations of employees, stakeholders and associates: number of people resigning from employment, number of stakeholders resigning from services,

- Measures based on assessment of institutional behaviour: adopted action strategies, implementation of adopted strategies, compliance with internal regulations and procedures,

- Time-related measures: short-term, long-term, at least a year (one financial year),

- Measures depending on the external situation: ease and speed of implementing legislative changes,
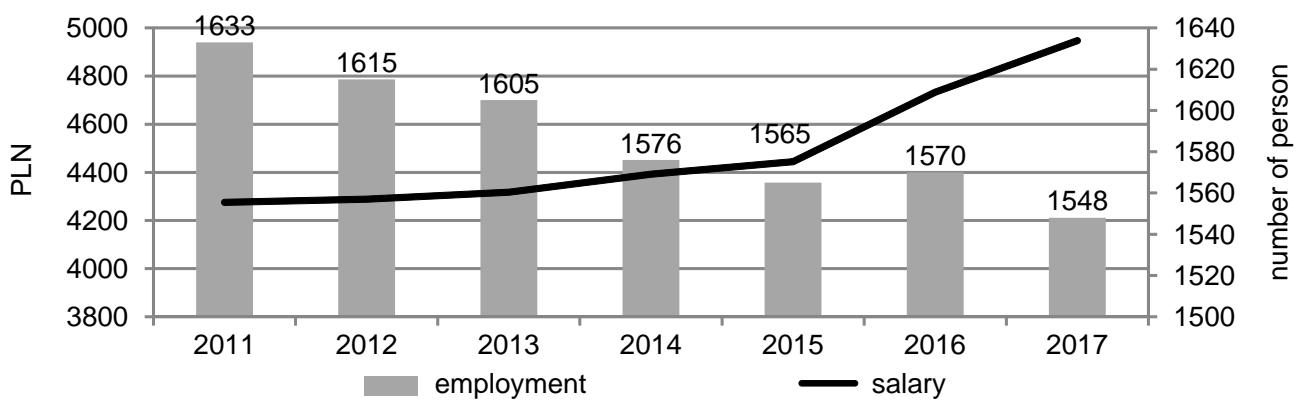

Fig. 3. Employment and average gross salary of the employees of the Central Office of Measures in 2011-2017 Source: Annual audit reports of the Supreme Audit Office [NIK 2011-2017]. 
resistance to political changes in the country, lack of disturbances in the functioning of the institution [Alińska 2016, pp. 56-57].

From this pool of measures, it is possible to distinguish those that accurately describe the phenomena that occurred in the Central Office of Measures in years 2011-2017. The measures, which seem most adequate with regard to finances, are measures based on quantitative assessment covering the value of received revenue, the average gross salary of full-time employees, lack of rapid changes in the value of expenditure and changes in the number of employees. The overall situation of the Central Office of Measures as an organisation can be evaluated with the measures based on the assessment of institutional behaviour, which examine adopted strategies of action, (when they refer to the future), and implementation of adopted strategies and their compliance with internal rules and procedures, (when they refer to the present). In addition, the measures based on subjective opinions, behaviours and expectations of employees, stakeholders and associates of the Central Office of Measures play a crucial role. By determining the number of people resigning from employment in the Office and the number of stakeholders withdrawing from cooperation, the Office status as an employer and service provider can be examined, which translates into an overall evaluation of its functionality.

The analysis of the aforementioned measures of financial stability related to various areas of functionality generated descriptive measures examining the stability of leadership in an organisation:

- Measure of time - a minimum period of time necessary to obtain information on the occurrence of certain repetitive phenomena as a result of functional activities in various areas of the institution has been determined. Persons in managerial positions in the office should become familiar with the specifics of the overviewed operations (minimum in one cycle) to be able to properly assess statutory activities and then manage them effectively.

- Measure of rules - a set of rules, legal provisions and internal procedures, compliance with which is the basic determinant of the correct and stable functioning of the office. These rules are set and monitored by the office authorities.
- Measure of transparency in dealing with external changes - smooth adaptation of the office operations to the inevitable external changes (including amendments to existing legislative acts), remaining apolitical, keeping pace with technological progress and focusing on achieving the set goals regardless of adverse external factors utilising the risk-management measures.

- Measure of proper management of financial resources - managing financial resources has impact on the functioning of all areas of the institution including remuneration, which is a form of motivating staff, other current expenditure ensuring smooth operation of the office, investment expenditure ensuring a better quality of services rendered by the office as well as enhanced working conditions for employees and revenue which should be properly accounted in terms of tax liabilities.

The main purpose of the study was to demonstrate how the destabilization of leadership can affect various areas of a state office's operation. The literature review and the collected research material have led to the following conclusions:

- The measure based on quantitative assessment (embracing the received revenues, the average gross salary of full-time employees in the PFSU, the lack of rapid changes in incurred expenditures and changes in the number of employees) juxtaposed with the data obtained from the annual audit reports of the Supreme Audit Office shows that during the period of leadership instability disturbances were recorded in the aforementioned areas. The carried out revenues recorded a significant increase (2016), followed by a decrease (2017), the salaries increased significantly, which indicates a good financial standing of the entity. On the other hand, the collected data show an alarmingly rapid increase in the level of expenses and decreasing number of employees.

- The measure based on the assessment of institutional behaviour analyses adopted strategies, assesses the implementation of predetermined strategies and checks their compliance with the rules and internal procedures of the PFSU. Based on the obtained information, it was concluded that the Office's action plan for years 2010-2015 had not 
been positively assessed. A new, comprehensive stategic action plan was prepared and adopted for subsequent years (2018-2021), which eliminates the errors of the previous strategy, as noticed and pointed out by the auditors from the Supreme Audit Office, and presents the organisation as a modern and innovative institution in a very professional manner consistent with modern standards [GUM 2017].

- The measure based on the subjective opinions, behaviours and expectations of employees, stakeholders and associates of the PFSU utilises data like the number of people resigning from employment in the Office or the number of stakeholders no longer using the Office's services and leads to conclusions regarding the Office's status as an employer and service provider. According to information obtained from an employee of the Human Resources and Professional Development Department, the aforementioned downward trend in the number of employees resulted from termination of employment contracts by mutual consent. However, observing the fall in revenues in 2017 , it can be assumed that in fact it results from the decreasing number of stakeholders using the services provided by the analysed PFSU.

- The measures describing the stability of leadership itself have been linked to such phenomena as the long-time tenure of senior positions, the authorities' respect for and monitoring of the applicable procedures, transparency in dealing with changing external regulations and effective management of financial resources. The analysis of the activity of the PFSU in years 2011-2017, showed that the guidelines of the measure describing the stability of leadership had not been fully implemented. In 2016 and 2017, several senior managerial positions in the Office were filled and re-filled several times. This situation resulted from lack of decision-makers' expertise concerning the functioning of this organisation, which in turn affected decisions on finances, personnel, procedures and legislation. The strategy for years 2018-2021 eliminates the noted failings of the preceding document and assumes the development and transformation of PFSU into an innovative metrological institute matching up to similar institutions in countries with a high level of economic development.

\section{REFERENCES}

Alińska, A. (2016). Istota, mierniki i ocena stabilności publicznego systemu finansowego w kontekście doświadczeń globalnego kryzysu finansowego. Ekonomiczne Problemy Usług, 125, 49-59.

Balicki, R. (2018). Konstytucyjne uwarunkowania stabilności Rady Ministrów. Ruch Prawniczy, Ekonomiczny i Socjologiczny, 80 (1), 205-213.

Bath, P. (2001). Resource for Success Series. Virginia: USA Nature Conservancy, Arlington VA.

Główny Urząd Miar - GUM (2010). Cele strategiczne Głównego Urzędu Miar na lata 2010-2015. Warszawa.

Główny Urząd Miar - GUM (2017). Czteroletni strategiczny plan działania Głównego Urzędu Miar 2018-2021. Warszawa.

Kuźmiński, A.K. (2020). Zarządzanie. Teoria i praktyka. Wydawnictwo Naukowe PWN, Warszawa.

Lubińska, T. (2011). Kierunki modernizacji zarządzania w jednostkach samorządu terytorialnego. Difin, Warszawa.

Najwyższa Izba Kontroli - NIK (2011). Sprawozdanie z działalności Najwyższej Izby Kontroli w 2011 roku. Warszawa.

Najwyższa Izba Kontroli - NIK (2012). Sprawozdanie z działalności Najwyższej Izby Kontroli w 2012 roku. Warszawa.

Najwyższa Izba Kontroli - NIK (2013). Sprawozdanie z działalności Najwyższej Izby Kontroli w 2013 roku. Warszawa.

Najwyższa Izba Kontroli - NIK (2014). Sprawozdanie z działalności Najwyższej Izby Kontroli w 2014 roku. Warszawa.

Najwyższa Izba Kontroli - NIK (2015). Sprawozdanie z działalności Najwyższej Izby Kontroli w 2015 roku. Warszawa.

Najwyższa Izba Kontroli - NIK (2016). Sprawozdanie z działalności Najwyższej Izby Kontroli w 2016 roku. Warszawa.

Najwyższa Izba Kontroli - NIK (2017). Sprawozdanie z działalności Najwyższej Izby Kontroli w 2017 roku. Warszawa.

Navarro-Galera, A., Rodriquez-Bolivar, M.P., Alcaide-Munoz, L., Lopez-Subires, M.D. (2016). Measuring the financial sustainability and its influential factors in local governments. Applied Economics, 48 (41), 3961-3975. 
Prowle, M. (2000). The changing public sector: A practical management guide. Gower Publishing, Hampshire.

Shepherd, B. (2010). Political Stability: Crucial for Growth? LSE IDEAS Strategic Brief, March, 8-11. Retrieved from http:/www.lse.ac.uk/international-relations/assets/documents/dinam/Dinam.Shepherd.Ben. Political-Stability-Crucial-for-Growth.pdf $\quad$ [accessed 20.10.2019].

Skoczylas-Tworek, A. (2013). Budżet zadaniowy jako wyzwanie dla audytorów wewnętrznych jednostek sektora finansów publicznych. Zeszyty Naukowe Uniwersytety Szczecińskiego, 766, 193-207.

Ustawa z dnia 21 listopada 2008 r. o służbie cywilnej. Dz.U. $2008 \mathrm{nr} 227$, poz. 1505 [Civil Service Act of 21 November 2008. Journal of Laws of 2008 No 227, item 1505].
Ustawa z dnia 24 lipca 1998 r. o wprowadzeniu zasadniczego trójstopniowego podziału terytorialnego państwa. Dz.U. 1998 nr 96, poz. 603 [Act of 24 July 1998 on the introduction of a basic three-tier territorial division of the state. Journal of Laws of 1998 No 96, item 603].

Weber, M. (1998). Polityka jako zawód i powołanie. SIW Znak, Fundacja im. Stefana Batorego, Kraków-Warszawa.

Włóka, M., Jędrzejas, N. (2014). Teoretyczne aspekty zarządzania strategicznego w kontekście funkcjonowania podmiotów administracji publicznej. Zeszyty Naukowe Politechniki Częstochowskiej. Zarządzanie, 14, 88-100

Zawicki, M. (2011). Nowe zarządzanie publiczne. PWE, Warszawa.

\section{STABILNOŚĆ WŁADZY JAKO DETERMINANT ROZWOJU JEDNOSTEK BUDŻETOWYCH}

\section{STRESZCZENIE}

W opracowaniu przedstawiono istotę pojęcia stabilności państwa oraz pojęcia sektora finansów publicznych na podstawie przeglądu literatury przedmiotu. Podjęto próbę wskazania zasad zarządzania publicznego oraz przedstawiono struktury jednostek sektora finansów publicznych (jsfp) w Polsce. Opracowanie skupia sią na zagadnieniach sektora finansów publicznych, jednostkach wchodzących w jego skład oraz mechanizmach wpływających na sposób funkcjonowania i zarządzania jego obszarami. Cześć pracy poświęcono analizie przykładowej jsfp jako centralnego organu administracji. Celem opracowania jest zidentyfikowanie mierników wykorzystywanych do szacowania stabilności jsfp oraz interpretacja tych mierników w odniesieniu do badanych obszarów funkcjonowania sektora finansów publicznych w Polsce. Scharakteryzowano zasady zarządzania organizacją sektora finansów publicznych oraz przedstawiono pojęcie zarządzania publicznego wraz z jego genezą. Na przykładzie jednostki finansów publicznych podjęto próbę wskazania zależności między funkcjonowaniem jsfp a stabilnością władzy w tej jednostce. Opracowanie jest opisowe i wykorzystuje metody wnioskowania. Literatura przedmiotu z zakresu finansów publicznych i zarządzania oraz materiały wewnętrzne jsfp stanowiły materiał badawczy. Zasadniczym celem opracowania jest wskazanie, w jaki sposób destabilizacja władzy może wpłynąć na obszary funkcjonowania państwowego urzędu. Jako efekt prowadzonej analizy skonstruowano wzorce mierników najtrafniej opisujących zjawisko stabilności władzy: miernik oceny ilościowej w zakresie uzyskiwanych dochodów, wysokości przeciętnego wynagrodzenia brutto pełnozatrudnionych w jsfp; miernik oceny zachowań instytucjonalnych, dzięki któremu można analizować przyjęte strategie działania, oceniać realizację przyjętych strategii oraz sprawdzać jakość oraz sposób przestrzegania przepisów i procedur wewnętrznych jsfp; miernik subiektywnych opinii, zachowań oraz oczekiwań pracowników, kontrahentów i współpracowników jsfp. Potwierdzono istnienie zależności między stabilnością władzy a funkcjonowaniem jsfp. Dostrzeżono zmiany w funkcjonowaniu urzędu w okresie częstych zmian personalnych na wyższych stanowiskach służby cywilnej.

Słowa kluczowe: sektor finansów publicznych, stabilność, zarządzanie publiczne 